\title{
SURVIVAL OF A NATIVE MAMMALIAN CARNIVORE, THE LEOPARD CAT Prionailurus bengalensis KeRR, 1792 (CARNIVORA: FelidAe), IN AN AGRICULTURAL LANDSCAPE ON AN OCEANIC PHILIPPINE ISLAND
}

\section{Ma. Renee P. Lorica ${ }^{1}$ \& Lawrence R. Heaney ${ }^{2}$}

${ }^{1}$ Conservation Biology Program, University of Minnesota, 200 Hodson Hall, 1980 Folwell Ave., St. Paul, MN 55108, USA ${ }^{1}$ Current address: Crop and Environmental Science Division, International Rice Research Institute, Los Baños, Laguna 4031, Philippines

${ }^{2}$ Division of Mammals, Field Museum of Natural History, 1400 S. Lake Shore Drive, Chicago, IL 60605, USA

${ }^{1}$ loric001@umn.edu (corresponding author), ${ }^{2}$ Iheaney@fieldmuseum.org

\begin{abstract}
Concerns about vulnerability of mammalian carnivores to extinction, especially on small islands, appear to conflict with prior reports of endemic populations of leopard cat Prionailurus bengalensis (Kerr, 1792) surviving in agricultural landscapes on oceanic islands. We investigated the persistence of the Visayan leopard cat ( $P . b$. rabori) in the sugarcane fields on Negros, an oceanic island in central Philippines. A population remained throughout the year at our study site on a sugarcane farm, and reproduction was noted. Non-native rodents form the bulk of the cat's diet, followed by reptiles, birds, amphibians, and insects. Prey species identified from the samples commonly occur in agricultural areas in the Philippines. Prey composition did not vary significantly with respect to wet and dry season, or sugarcane harvest cycle. This study provides evidence that an intensively managed agricultural landscape on this oceanic island supports a native obligate carnivore that subsists primarily on exotic rats. This study supports a prior prediction that leopard cats will show flexibility in prey selection on islands with few or no native small mammal prey species, but in this case they do so not by switching to other vertebrates and invertebrates, but rather to exotic pest species of rodents.
\end{abstract}

Key words: Diet, exotic rats, extinction threat, habitat use, islands, Negros Island, prey selection, Prionailurus bengalensis, scats

Abbreviations: bp - base pair; DNA - deoxyribonucleic acid; GPS - global positioning system; IUCN - International Union for Conservation of Nature

DOI: http://dx.doi.org/10.11609/JoTT.o3352.4451-60 | ZooBank: urn:Isid:zoobank.org:pub:82D6D568-193A-4062-9A67-23401B554833

Editor: Shomita Mukherjee, Salim Ali Centre for Ornithology and Natural History, Coimbatore, India.

Date of publication: 26 June 2013 (online \& print)

Manuscript details: Ms \# 03352 | Received 18 September 2012 | Final received 01 June 2013 | Finally accepted 02 June 2013

Citation: Lorica, M.R.P. \& L.R. Heaney (2013). Survival of a native mammalian carnivore, the leopard cat Prionailurus bengalensis Kerr, 1792 (Carnivora: Felidae), in an agricultural landscape on an oceanic Philippine island. Journal of Threatened Taxa 5(10): 4451-4460; http://dx.doi.org/10.11609/JoTT.o3352.4451-60

Copyright: ( Lorica \& Heaney 2013. Creative Commons Attribution 3.0 Unported License. JoTT allows unrestricted use of this article in any medium, reproduction and distribution by providing adequate credit to the authors and the source of publication.

Funding: We thank the following institutions for funding this project: Conservation Biology Program-University of Minnesota; Council of Graduate Student's Travel Fund; Dayton-Wilkie Natural History Funds; the Ellen Thorne Smith Fund of the Field Museum of Natural History; Ford Foundation-IFP; Ideawild; and, Rufford Small Grants.

Competing Interest: None

Acknowledgements: Our sincerest gratitude to the individuals who supported the project in various ways: Jeric Gonzalez; Steve Goodman; Shannon Hackett; Hda. Dos Marias staff; Michael Joyce; Kathleen Kelly; Pai Klinsawat; Gerry Ledesma; Paul Lizares; Dee-Ar Paglumotan; Alan Resetar; J.L. David Smith; Worawidh Wajjwalku; and, David Willard. Much appreciation to the Negros Forests \& Ecological Foundation, Inc. Permission to conduct this study was granted by the Department of Environment and Natural Resources-Region VI office; we especially thank RED Julian Amador and PAWD Chief Damaso Fuentes for their support. Dr. John McDonald and Patrick Zimmerman provided advice on the use of the Fisher's Exact Test. The maps were prepared by Andria Niedzielski. Danny Balete and Eric Rickart provided constructive suggestions that led to improvements in earlier drafts of this paper. We also thank the reviewer of this manuscript for the comments and suggestions.

Author Contribution: MRPL collected data from the field with the help of her research assistant; analyzed them with the help of LRH and wrote the basic draft of the dietary aspect of this paper. LRH guided MRPL on the methodology and data analysis, assisted with identifications of scat contents, and wrote most portions of the paper that deal with island biogeography.

Author Details: MA. RENEE P. LORICA is a wildlife biologist who has been studying Visayan leopard cats since 2005. She currently works for the International Rice Research Institute on rodent ecology in lowland rice fields in the Philippines. LAWRENCE R. HEANEY is principally interested in biogeography, ecology, evolution, and conservation of biodiversity in island ecosystems, and conducts most of his research on the mammals of the Philippines. He serves as Curator and Head of the Division of Mammals at the Field Museum of Natural History.
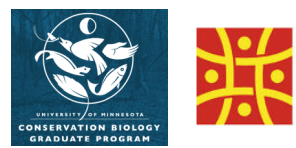

FORD FOUNDATION

INTERNATIONAL

FELLOWSHIPS PROGRAM
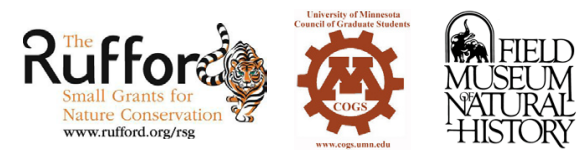


\section{INTRODUCTION}

Because of their high trophic level, high metabolism, and low population density, mammalian carnivores are considered to be among the organisms most vulnerable to extinction, often due to fragmentation of habitat or over-hunting (e.g., Primack 1993). This view of mammalian carnivores being vulnerable to extinction is especially prominent in literature on island biogeography. On post-Pleistocene land-bridge islands (and habitat islands of progressively smaller area), carnivore species richness declines more rapidly than any other group of mammals (e. g., Brown 1971; Heaney 1984; Lomolino et al. 2010) and they often are entirely absent from oceanic islands (e.g., Lawlor et al. 2002; Whittaker \& FernándezPalacios 2007).

This hypothesized vulnerability of native carnivores was strongly corroborated by an analysis of mammalian carnivores on East Asian islands, which found a strong correlation between carnivore species richness and island area, and an even stronger correlation between carnivore richness and prey richness (Watanabe 2009). That study highlighted what appears to be an incongruity with prior reports of a small native felid, the leopard cat Prionailurus bengalensis (Image 1), maintaining populations on several small oceanic islands, including Tsushima $\left(696 \mathrm{~km}^{2}\right)$ and Iriomote $\left(289 \mathrm{~km}^{2}\right)$ in Japan. Most populations of this cat occur on islands of $1000 \mathrm{~km}^{2}$ or larger, where at least seven species of native small mammals (Soricomorpha plus Rodentia) are present. However, on Tsushima only six native small mammals are present, and on Iriomote there are none. Watanabe's (2009) study, which focused on the leopard cat, concluded that "the probability of existence of the leopard cat is extremely low on small islands with poor small mammal fauna[s] and several species of carnivores". The study showed that on the two Japanese islands, leopard cats consumed large amounts of non-mammalian prey (e.g., birds, reptiles, amphibians, crustaceans, and insects). Their persistence on such small islands was evidence of versatility in feeding habits where close competitors, especially small carnivores of the family Viverridae, are absent (Watanabe 2009).

Despite their widespread occurrence, relatively few studies have been conducted on leopard cats (de Alwis 1973; Rabinowitz 1990; Bumstead et al. 1992; Nowell \& Jackson 1996). As Watanabe (2009) noted, leopard cats primarily feed on rodents and, usually to a lesser extent, birds, reptiles, amphibians and invertebrates (Inoue 1972; Yasuma 1981; Rabinowitz 1990; Sakaguchi 1990; Grassman 1998; Grassman 2000; Scott \& Gemita 2004;

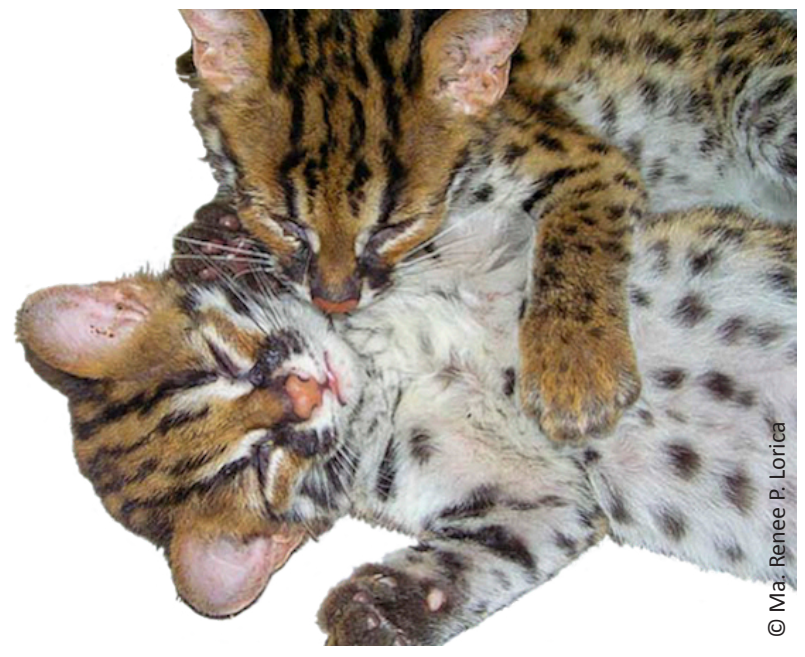

Image 1. Leopard cat Prionailurus bengalensis

Grassman et al. 2005; Austin et al. 2007; Rajaratnam et al. 2007). In some agricultural areas, their primary prey are exotic rat species that are major pests (Delibes et al. 1997; Stenseth et al. 2003). In an oil palm plantation in Sumatra, leopard cats moved through a complex matrix of habitats and fed on small mammals, including exotic pest rats and other small vertebrates and invertebrates (Scott \& Gemita 2004). Similarly, in Malaysian Borneo, a study of habitat selection in an oil palm plantation found that leopard cats relied heavily on small mammals, especially rodents, and also on reptiles and amphibians (Rajaratnam et al. 2007).

In the Philippines, leopard cats occur on islands that range from ca. $14,000 \mathrm{~km}^{2}$ down to $319 \mathrm{~km}^{2}$, where most native habitat has been converted to agricultural or human residential uses (Institute of Environmental Science for Social Change 2002; Lorica \& Oliver 2006; Pedregosa et al. 2006; Heaney et al. 2010). A subspecies of leopard cat endemic to the islands of the westcentral Philippines, Prionailurus bengalensis rabori Groves 1997, is listed as Vulnerable by the IUCN Red List of Threatened Species (Lorica 2008) and by the Philippine Department of Environment and Natural Resources (2004). They have been reported as extinct or close to extinction on the two smaller islands in their range, Cebu $\left(4468 \mathrm{~km}^{2}\right)$ and Masbate $\left(3270 \mathrm{~km}^{2}\right)$, and persist principally on Panay $\left(12,011 \mathrm{~km}^{2}\right)$ and Negros $\left(13,075 \mathrm{~km}^{2}\right)$, both of which have lost $90-95 \%$ of their natural habitat (Lorica \& Oliver 2006; Heaney et al. 2010). Previous publications concerning P.b. rabori on Negros Island have suggested that they may maintain populations in heavily utilized agricultural landscapes. As early as 1898, John Whitehead (cited in Taylor 1934) stated that, "In Negros we obtained a specimen of Felis 
minuta $[=P$. $b$. rabori]. The animal frequented sugarcane plantations, where it finds an abundance of rats. During the harvesting operations, this cat is often captured by the natives, who form a ring around the last patch of standing cane." Subsequent studies have provided some support for this observation (Alcala \& Brown 1969; Heideman et al. 1987; Lorica \& Oliver 2006; Fernandez \& de Guia 2011), though all were limited by focusing on captive animals, dealing with small samples, or relying on problematic methodologies. These islands have few or no native, non-volant small mammals (only two are known from Negros, three from Panay, and none are known from Cebu or Masbate), and two civets (family Viverridae) occur on all four islands (Steppan et al. 2003; Heaney et al. 2010).

The purpose of this study was to investigate the diet of wild leopard cats inhabiting a sugarcane farm on Negros Island to determine if they remain as a resident population on the farm throughout the year, reproduce on the farm, and subsist on exotic rats, as suggested by earlier studies. We conducted visual transects to detect tracks and scats, and determined prey through detailed analysis of scat contents whose origin was verified by DNA analysis. This allowed us to test the prediction of Watanabe (2009) that on an island with two native small mammals and two potential competitors, as is the case on Negros, leopard cats would have a broad feeding niche, with a highly diverse prey base that includes a relatively small percentage of small mammals.

\section{METHODS}

\section{Study site}

Like most Philippine islands, Negros arose from the ocean floor de novo (Hall 1996, 2002). Its volcanic origins make the soil ideal for agriculture, and about $80 \%$ of arable land has been cultivated. The land area (including small offshore islands) totals $13,328.4 \mathrm{~km}^{2}$, of which $2,091 \mathrm{~km}^{2}$ was planted to sugarcane, as of crop year 2011-2012 (Sugar Regulatory Administration, pers. comm. 25 January 2012).

Our study site, Hacienda Dos Marias, is a 238-hectare private sugarcane farm in Barangay Ara-al, La Carlota City, Negros Occidental. Throughout the perimeter of the hacienda, wooded areas and bamboo-dominated shrubby patches were present along the creeks and rivers. There are two small human settlement areas within the hacienda. Planted cover (Fig. 1) refers to monospecific stands of mahogany (Swietenia macrophylla), mixed plantations of exotic tree species, and one stand of a native tree (ilang-ilang, Cananga odorata). Heavily disturbed riparian vegetation of small trees and shrubs grew naturally along the banks of rivers and creeks. Bamboo groves were made up of either planted or naturally-growing bamboo species (Bambusa spp.) growing in clumps.

\section{Spoor observation and scat collection}

Scats and tracks were collected and observed, respectively, during transect walks for ten months within the study area from August 2010 to June 2011, and opportunistically elsewhere in the study area. Transects were conducted on a weekly basis, and on days within the week when transects are not walked, the study area was searched for scats. Scat, track and nest locations were georeferenced using a GPS device. Fifty four scats were observed but only 51 were collected and subsequently analyzed due to lack of teeth and bones from the three samples, though these samples were composed mostly of mammalian hair. Each sample was stored in a plastic container in $90 \%$ ethanol, and labeled accordingly. Several methods were used to ensure that scat samples, and tracks in the study were from leopard cats. Based on scats from captive leopard cats from a local rescue center, and from the literature (Rajaratnam et al. 2007; Fernandez \& de Guia 2011), we used the average diameter of $1-1.5 \mathrm{~cm}$ to distinguish leopard cat scats from scats of other carnivores in the area. The common palm civet Paradoxurus hermaphroditus is roughly the same size as the leopard cat while the Malay civet is generally larger (Nowak 2005; Heaney et al. 2010) and has larger scats. Scats from palm civets are about the same size as those of leopard cats, but contain more fruits than small vertebrates (Rabinowitz 1991; Joshi et al. 1995; Shore et al. 2005; Nakashima et al. 2010). Upon analysis of each scat, samples containing seeds and plant matter other than grass were discarded, as they could belong to either species of omnivorous viverrid in the area (Rabor 1977; Heideman et al. 1987). Finally, DNA analysis to confirm the origin of some scats was performed by the laboratory of Prof. Worawidh Wajjwalku at Kasetsart University. Thirty scat samples were analyzed, and of the 30 , only eight were found to have useful DNA, half of which were leopard cats, while two belong to its prey, Rattus tanezumi. The universal primer $\mathrm{cb0} / \mathrm{cb} 2$ (forward primer/reward primer) was used to amplify $420 \mathrm{bp}$ of the cytochrome $b$ region of the mitochondrial DNA. This primer is designed by Prof. W. Wajjwalku. The sequencing results were compared with those reported in $\mathrm{GenBank}^{\odot}$ sequences for species identification. 


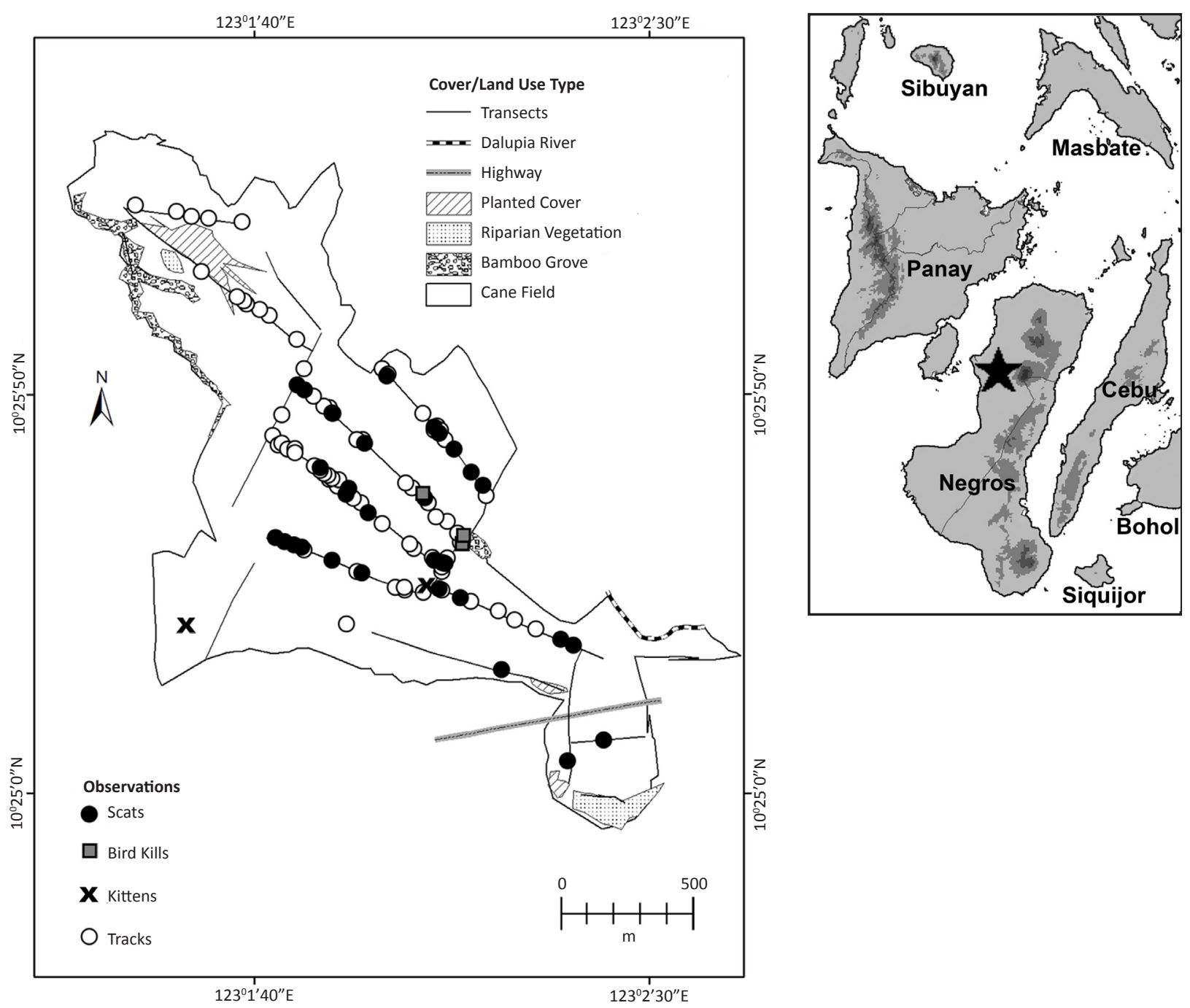

Figure 1. Map of the study site showing where spoors were observed on established transects relative to habitat type (see Methods). It also shows locations of active nests uncovered and bird kill points.

Domestic cats have also been observed around human habitation. We employed several means to distinguish leopard cat tracks from that of a domestic cat. Those that accompany scats that were proven to be of a leopard cat's via DNA analysis were included. Tracks found in close proximity to human habitation were immediately discarded. We did not include tracks or scats from such places in our analyses; these scats (which were not subjected to DNA analysis) typically contained undigested rice, pieces of plastic food wrappers, and house mouse skeletal remains. This procedure may have led us to exclude actual leopard cat tracks and/or scats (from places near houses), and to include some house cat scats (from places away from houses), but we believe it substantially reduces the likelihood of misidentifications overall.

\section{Scat analysis}

Each sample was placed in a 1-mm sieve and washed with hot water to separate the elements in the scat. Only bones, teeth, scales and feathers were collected from each scat sample, dried, and kept in small envelopes for identification. Hair was not used as the basis for identification given the variability of its morphology even between individuals of the same species (Mayer 1952; Dagnall 1995; Broeck et al. 2000). These samples were compared against specimens at the Field Museum of Natural History, Chicago, Illinois. Data were analyzed using $R$ version 2.13.2 ( ${ }^{\odot}$ The $R$ Foundation for Statistical Computing). Fisher's Exact Test was used due to small sample size (McDonald 2009). 
Table 1. Spoor observed per transect divided according to sugarcane harvest cycle.

\begin{tabular}{|c|c|c|c|c|c|c|c|c|c|c|}
\hline \multirow{2}{*}{$\frac{\text { Transect/Cover* }}{\text { Months }}$} & \multicolumn{2}{|c|}{ Preharvest } & \multicolumn{6}{|c|}{ Harvest } & \multicolumn{2}{|c|}{ Postharvest } \\
\hline & Sep & Oct & Nov & Dec & Jan & Feb & Mar & Apr & May & Jun \\
\hline 1 Riparian bamboo & - & - & - & - & - & - & - & - & - & - \\
\hline 2a Wooded scrub+ & - & - & - & - & - & 1 & - & - & - & - \\
\hline 2b Wooded scrub+ & & 1 & & 1 & - & - & 1 & & - & - \\
\hline $2 c+$ & 1 & - & - & - & - & - & - & - & - & - \\
\hline $3+$ & 1 & - & - & - & - & - & - & 1 & - & - \\
\hline $4+$ & - & - & - & 1 & 1 & - & - & - & 1 & - \\
\hline 5aCommunity+ & - & - & - & - & - & - & - & - & - & - \\
\hline $5 b+$ & 1 & - & - & - & - & - & - & - & - & - \\
\hline $5 c+$ & - & - & - & - & - & - & - & - & - & - \\
\hline $6 a+$ & - & - & 1 & 1 & 1 & 1 & - & - & - & 1 \\
\hline $6 b+$ & - & - & 1 & 1 & 1 & 1 & & - & - & 1 \\
\hline $7 a+$ & 1 & 1 & 1 & - & - & - & - & 1 & 1 & 1 \\
\hline 7b Bamboo patch+ & 1 & - & - & - & - & 1 & & - & - & 1 \\
\hline $8 a+$ & 1 & 1 & 1 & & - & 1 & - & 1 & - & 1 \\
\hline $8 b+$ & & 1 & 1 & - & - & 1 & 1 & 1 & - & - \\
\hline 9aCommunity+ & - & 1 & - & - & - & - & - & - & - & - \\
\hline $9 b+$ & 1 & 1 & - & - & - & - & - & - & 1 & - \\
\hline $10 a+$ & - & - & - & 1 & 1 & - & - & - & - & \\
\hline $10 b+$ & - & 1 & - & - & - & 1 & - & - & - & - \\
\hline 11Commun/Ranch+ & - & - & - & - & - & - & - & - & - & - \\
\hline $12+$ & - & - & - & - & - & - & - & - & - & \\
\hline 13a llang-ilang+ & - & - & - & - & - & - & 1 & - & - & - \\
\hline $13 b+$ & 1 & - & - & 1 & - & - & - & - & - & - \\
\hline $14+$ & - & 1 & - & - & - & - & - & - & - & 1 \\
\hline $15 a+$ & - & - & - & - & - & - & - & - & - & - \\
\hline 15bRoad/Mahogany+ & - & - & - & - & - & - & - & - & - & - \\
\hline 16Riparian & - & - & - & - & - & - & - & - & - & - \\
\hline Total Observed & 8 & 8 & 5 & 6 & 4 & 7 & 3 & 4 & 3 & 6 \\
\hline
\end{tabular}

+Also planted with sugarcane

\section{RESULTS}

\section{Site use}

Leopard cats were active throughout the study area (Fig. 1), as documented by scats and tracks. In two cases, nests with kittens were uncovered by workers during the harvest. Three bird kills were found in the study area; we cannot be certain that they were attributable to leopard cats, but this was likely because tracks and feces of leopard cats were found nearby.

Leopard cat activity occurred during every month of the study. The pre-harvest season (September-October), when cane was tall and not often disturbed by human activity, yielded the highest observation of spoor: eight out of 27 sub-transects were found to contain leopard cat signs of presence during both months (Table 1). During the harvest months of November to April, the average number of spoors observed was 4.8 /month, and during the post-harvest months of May and June, the average was $4.5 /$ month. Fisher's Exact Test $(P>0.05)$ showed no significant differences among the three periods, perhaps associated with the small sample sizes, in spite of the larger number observed in the pre-harvest period.

We also examined the presence of spoor according to climatic seasons (Table 2). The wet season $(n=4)$ yielded an average of 6.75 observations/month, and the dry season yielded an average of $4.5 /$ month. This difference was not statistically significant (Fisher's Exact 
Table 2. Spoor observed per transect divided according to climatic seasons.

\begin{tabular}{|c|c|c|c|c|c|c|c|c|c|c|}
\hline \multirow{2}{*}{$\begin{array}{r}\text { Transect/Cover } \\
\text { Months }\end{array}$} & \multicolumn{4}{|c|}{ Wet } & \multicolumn{6}{|c|}{ Dry } \\
\hline & Sep & Oct & Nov & Dec & Jan & Feb & Mar & Apr & May & Jun \\
\hline 1 Riparian bamboo & - & - & - & - & - & - & - & - & - & - \\
\hline 2a Wooded scrub+ & - & - & - & - & - & - & 1 & - & - & - \\
\hline 2b Wooded scrub+ & - & - & 1 & - & 1 & - & - & 1 & - & - \\
\hline $2 \mathrm{c}+$ & - & 1 & - & - & - & - & - & - & - & - \\
\hline $3+$ & - & 1 & - & - & - & - & - & - & 1 & - \\
\hline $4+$ & - & - & - & - & 1 & 1 & - & - & - & 1 \\
\hline 5aCommunity+ & - & - & - & - & - & - & - & - & - & - \\
\hline $5 b+$ & - & 1 & - & - & - & - & - & - & - & - \\
\hline $5 c+$ & 1 & - & - & 1 & 1 & 1 & 1 & - & - & - \\
\hline $6 a+$ & 1 & - & - & 1 & 1 & 1 & 1 & - & - & - \\
\hline $6 b+$ & 1 & 1 & 1 & 1 & - & - & - & - & 1 & 1 \\
\hline $7 a+$ & 1 & 1 & - & - & - & - & 1 & - & - & - \\
\hline 7b Bamboo patch+ & 1 & 1 & 1 & 1 & - & - & 1 & - & 1 & - \\
\hline $8 a+$ & - & - & 1 & 1 & - & - & 1 & 1 & 1 & - \\
\hline $8 b+$ & - & - & 1 & - & - & - & - & - & - & - \\
\hline 9aCommunity+ & - & 1 & 1 & - & - & - & - & - & - & - \\
\hline $9 b+$ & - & - & - & - & 1 & 1 & - & - & - & 1 \\
\hline $10 a+$ & - & - & 1 & - & - & - & 1 & - & - & - \\
\hline $10 b+$ & - & - & - & - & - & - & - & - & - & - \\
\hline 11Commun/Ranch+ & - & - & - & - & - & - & - & - & - & - \\
\hline $12+$ & - & - & - & - & - & - & - & 1 & - & - \\
\hline 13a Ilang-ilang+ & - & 1 & - & - & 1 & - & - & - & - & - \\
\hline $13 b+$ & 1 & - & 1 & - & - & - & - & - & - & - \\
\hline $14+$ & - & - & - & - & - & - & - & - & - & - \\
\hline $15 a+$ & - & - & - & - & - & - & - & - & - & - \\
\hline 15bRoad/Mahogany+ & - & - & - & - & - & - & - & - & - & - \\
\hline 16Riparian & - & - & - & - & - & - & - & - & - & - \\
\hline Total Observed & 6 & 8 & 8 & 5 & 6 & 4 & 7 & 3 & 4 & 3 \\
\hline
\end{tabular}

+Also planted with sugarcane

Table 3. Frequency of occurrence of the different vertebrate groups in leopard cat scats.

\begin{tabular}{|l|c|c|}
\hline Taxa & $\begin{array}{c}\text { Frequency of } \\
\text { Occurrence }\end{array}$ & $\begin{array}{c}\text { Percentage of } \\
\text { Occurrence }\end{array}$ \\
\hline Mammalia & 49 & 96 \\
\hline Aves & 6 & 12 \\
\hline Reptilia & 10 & 20 \\
\hline Amphibia & 4 & 8 \\
\hline Insecta & 2 & 4 \\
\hline Unknown & 1 & 2 \\
\hline Grass & 17 & 33 \\
\hline Total Number of Scats & $\mathbf{5 1}$ & \\
\hline
\end{tabular}

Test, $\mathrm{P}>0.05)$.

\section{Evidence of reproduction}

During the harvest period, cane cutters found two litters within the study area (Fig. 1). A litter found on 1 March 2011 consisted of two kittens that were about 2-3 weeks old; the second litter, found 10 March 2011, was a lone kitten of about 4-5 weeks old. Two additional litters were rescued from areas adjacent to the study site; one was a lone kitten and the other a litter of three, all of which were less than a month old.

\section{Food habits}

Fifty one leopard cat scat samples were examined. 
Table 4. Taxonomic composition of prey according to sugarcane harvest cycle $(n=51)$.

\begin{tabular}{|c|c|c|c|c|c|}
\hline & $\begin{array}{c}\text { Pre- } \\
\text { harvest }\end{array}$ & Harvest & $\begin{array}{c}\text { Post- } \\
\text { harvest }\end{array}$ & Total & $\begin{array}{l}\text { Freq. } \\
\text { Oc. \% }\end{array}$ \\
\hline \multicolumn{6}{|l|}{ Mammals } \\
\hline Mus musculus & 2 & 0 & 0 & 2 & 3.9 \\
\hline Rattus exulans & 4 & 22 & 4 & 30 & 58.8 \\
\hline Rattus norvegicus & 2 & 1 & 0 & 3 & 5.9 \\
\hline Rattus tanezumi & 9 & 18 & 7 & 34 & 66.7 \\
\hline Rattus sp. & 0 & 2 & 1 & 3 & 5.9 \\
\hline Mammalian & 0 & 2 & 1 & 3 & 5.9 \\
\hline Amphibians (Ranidae) & 1 & 3 & 0 & 4 & 7.8 \\
\hline \multicolumn{6}{|l|}{ Reptiles } \\
\hline Gekkonid & 0 & 1 & 1 & 2 & 3.9 \\
\hline Varanus nuchalis & 1 & 0 & 0 & 1 & 2.0 \\
\hline Agamid & 0 & 1 & 0 & 1 & 2.0 \\
\hline Eutropis multifasciata & 2 & 0 & 0 & 2 & 3.9 \\
\hline Serpentes & 0 & 1 & 0 & 1 & 2.0 \\
\hline Unknown reptiles & 0 & 3 & 0 & 3 & 5.9 \\
\hline \multicolumn{6}{|l|}{ Birds (Passerine) } \\
\hline Lonchura leucogastra & 0 & 1 & 0 & 1 & 2.0 \\
\hline Pycnonotus goiavier & 0 & 1 & 0 & 1 & 2.0 \\
\hline Unknown birds & 0 & 2 & 1 & 3 & 5.9 \\
\hline \multicolumn{6}{|l|}{ Insects } \\
\hline Orthoptera & 0 & 1 & 0 & 1 & 2.0 \\
\hline Unknown insect & 0 & 1 & 0 & 1 & 2.0 \\
\hline UNKNOWN & 0 & 0 & 1 & 1 & 2.0 \\
\hline Grass & 5 & 12 & 0 & 17 & 33.3 \\
\hline
\end{tabular}

Mammals were present in $96 \%$ of the scats. Grass (33\%), reptiles $(20 \%)$, birds $(12 \%)$, amphibians $(8 \%)$ and insects (4\%) also occurred in the samples (Table 3 ). These percentages represent the relative frequency of occurrence of each prey group in all 51 scat samples. There was one sample in which the prey species could not be identified due to the breakdown of the bones to unidentifiable pieces, and the absence of teeth.

Among mammal species (Table 4), Rattus tanezumi was most frequently represented in scats (67\%), followed by $R$. exulans (34\%). Rattus norvegicus and Mus musculus were present but uncommon. Three samples were identified only to the genus Rattus, while three were identified only as mammalian. All of these rodents are non-native species. Amphibians could be identified only to the family level, Ranidae; reptiles were also identified only to the family level, Gekkonidae and Agamidae. Two scat samples were found to contain skink bones; one species of skink is most likely to occur
Table 5. Taxonomic composition of prey according to climatic seasons $(n=51)$.

\begin{tabular}{|c|c|c|c|c|}
\hline & Wet & Dry & Total & Freq. Oc. \% \\
\hline \multicolumn{5}{|l|}{ Mammals } \\
\hline Mus musculus & 2 & 0 & 2 & 3.9 \\
\hline Rattus exulans & 8 & 22 & 30 & 58.8 \\
\hline Rattus norvegicus & 2 & 1 & 3 & 5.9 \\
\hline Rattus tanezumi & 16 & 18 & 34 & 66.7 \\
\hline Rattus sp. & 1 & 2 & 3 & 5.9 \\
\hline Mammalian & 1 & 2 & 3 & 5.9 \\
\hline Amphibians (Ranidae) & 1 & 3 & 4 & 7.8 \\
\hline \multicolumn{5}{|l|}{ Reptiles } \\
\hline Gekkonid & 1 & 1 & 2 & 3.9 \\
\hline Varanus nuchalis & 1 & 0 & 1 & 2.0 \\
\hline Agamid & 0 & 1 & 1 & 2.0 \\
\hline Eutropis multifasciata & 2 & 0 & 2 & 3.9 \\
\hline Serpentes & 0 & 1 & 1 & 2.0 \\
\hline Unknown reptiles & 0 & 3 & 3 & 5.9 \\
\hline \multicolumn{5}{|l|}{ Birds (Passerine) } \\
\hline Lonchura leucogastra & 0 & 1 & 1 & 2.0 \\
\hline Pycnonotus goiavier & 0 & 1 & 1 & 2.0 \\
\hline Unknown birds & 1 & 2 & 3 & 5.9 \\
\hline \multicolumn{5}{|l|}{ Insects } \\
\hline Orthoptera & 0 & 1 & 1 & 2.0 \\
\hline Unknown insect & 0 & 1 & 1 & 2.0 \\
\hline UNKNOWN & 1 & 0 & 1 & 2.0 \\
\hline Grass & 5 & 12 & 17 & 33.3 \\
\hline
\end{tabular}

in the cane fields, Eutropis multifasciata (A. Diesmos pers. comm. 21 August 2011 \& R. Brown pers. comm. 14 October 2011). Snake bones were only identified to the suborder Serpentes, while three scats contained unidentified reptilian bones.

Two species of birds were identified from feathers, the Yellow-vented Bulbul Pycnonotus goiavier and the White-bellied Munia Lonchura leucogastra. Insect parts were also found in two of the scat samples; one was identified as orthopteran while the other was an unidentified insect.

Therewasnosignificant difference in preycomposition between pre-harvest, harvest, and post-harvest seasons (Fisher's Exact Test, P>0.05; Table 4). There was also no significant difference in rodent species occurrence in the scats between pre-harvest, harvest, and post harvest seasons (Fisher's Exact Test, $\mathrm{P}>0.05$ ).

There wasnosignificant difference in preycomposition between wet and dry seasons (Fisher's Exact Test, $\mathrm{P}$ 
$>0.05$; Table 5). There was also no significant difference in rodent species occurrence in the scats between wet and dry seasons (Fisher's Exact Test, P>0.05).

\section{DISCUSSION AND CONCLUSION}

\section{Site use}

Tracks and scats were found on nearly all transects in the study area (Fig. 1). Our transects principally followed unpaved roads and trails within sugar cane fields, since tracks and scats are easiest to see where there is no ground cover, and because leopard cats tend to deposit scats in open areas. Signs are more difficult to detect in natural habitats, such as riparian areas with ground cover. This possibly accounts for our few observations of spoor in natural habitats, even if the cats use those areas. The nearness of some spoor to areas heavily used by humans suggests that these leopard cats tolerate human proximity.

The two litters found within the study site further demonstrate that adult females use the cane fields, as reported by John Whitehead in 1898 (cited in Taylor 1934). Given the gestation period of leopard cats of 56-70 days (Nawa 1968; Hemmer 1976), the age of the kittens from each litter, and the close proximity between the dates of discovery, it can be inferred that the study site had at least two adult female leopard cats. The two other litters were found in the area bordering the study site, though GPS locations for these were not recorded due to unreliable information from workers in the other hacienda. This is consistent with information from a local rescue center that has received donations of unweaned kittens rescued from sugarcane farms near our study area since 1997 (Lorica \& Oliver 2006).

Previous studies have shown leopard cats to occur in a range of habitats, including primary and secondary forest, mixed agriculture and secondary forest, and mixed oil palm plantations and secondary forest (Taylor 1934; Lekagul \& McNeely 1977; Rabor 1977; Sunquist \& Sunquist 2002; Scott \& Gemita 2004; Lorica \& Oliver 2006; Rajaratnam et al. 2007). Our study site appears to represent the most heavily disturbed, most purely agricultural site at which this species has been shown to maintain a population.

\section{Diet composition}

Most previous studies have shown that mammals dominate the diet of leopard cats throughout its range (Alcala \& Brown 1969; Inoue 1972; Lekagul \& McNeely 1977; Santiapillai \& Suprahman 1985; Rabinowitz 1990;
Sakaguchi \& Ono 1994; Tatara \& Doi 1994; Grassman 1998; Grassman 2000; Grassman et al. 2005; Austin et al. 2007; Rajaratnam et al. 2007; Fernandez \& de Guia 2011). Earlier studies conducted in predominantly forested areas found that rodents, usually murids, were the most prominent mammalian prey. In Huai Kha Khaeng Wildlife Sanctuary in Thailand, rodents occurred in $76.3 \%$ of the scats (Rabinowitz 1990). In north-central and in central Thailand, high frequencies of occurrence for rodents ( $89 \%$ and $82 \%$, respectively), were also found (Grassman et al. 2005). In south-central Thailand, rodent frequencies were lower at $36 \%$, but mammals in total were the predominant prey (Grassman 2000). Murid rodents dominated the diet of leopard cats in the Sundarbans in Bangladesh, though the frequency was not as high at $52 \%$ (Khan 2004).

Leopard cats take a wide variety of mammalian prey. Aside from murid rodents, which were the primary prey overall, other small mammals found by the previously mentioned studies were bamboo rats (Spalacidae: Cannomys badius), squirrels (Sciuridae: Callosciurus spp., Menetes berdmorei, Petaurista petaurista, Tamiops spp.), tree shrews (Tupaiidae: Tupaia glis), gymnures (Erinaceidae: Hylomys suillus), and fruit bats (Pteropodidae: Pteropus dasymallus,); medium-sized mammals include hare (Leporidae: Lepus peguensis), hog badger (Mustelidae: Arctonyx collaris) and chevrotain (Tragulidae: Tragulus javanicus). Remains of relatively large-bodied mammals, such as pigs (Suidae: Sus scrofa) and langur (Cercopithecidae: Semnopithecus obscurus) were also found in the scats although some surmised that those had been scavenged rather than hunted (Santiapillai \& Suprahman 1985; Grassman 1998).

On Tsushima Island in Japan, rodents were found in $73 \%$ of the scats, but birds and insects were found in $42 \%$ and $44 \%$ of the scats, respectively (Inoue 1972), which are much higher rates than noted elsewhere. On Iriomote Island, Japan, rodents were found in only $20 \%$ of the scats, birds in $48 \%$, reptiles in $33 \%$, amphibians in 34\%, and insects in 24\% (Watanabe 2004, 2009; see also Sakaguchi 1990), leading Watanabe (2009) to predict that on any islands with few or no native rodents or shrews (such as Negros), leopard cats would show similar flexibility in prey selection, with great diversity in the taxa consumed.

We found mammals in $96 \%$ of our samples. There are ca. 41 species of bats inhabiting the island, many of which occur in agricultural lowlands (Heaney et al. 2010), but chiropterans were not found as prey in this study. One shrew (Crocidura negrina) and one mouse (Apomys sp.) are native to Negros, but both are confined 
to high-elevation forest (Heideman et al. 1987; Steppan et al. 2003; Heaney et al. 2010), and neither was present in our samples. Suncus murinus, the Asian house shrew, occurs in human habitation and agricultural areas on Negros, but it also was not found in this study. Of the four rodent species that made up the great majority of leopard cat prey at our study site, all are non-native pest species. Rattus tanezumi (a member of the Rattus rattus group) occurred most frequently in the scats (66.7\%); $R$. exulans (58.8\%) and $R$. norvegicus (5.9\%) followed. Mus musculus, more commonly associated with human habitation than agricultural areas in the Philippines (Heaney et al. 2010), occurred in only 3.9\% of the samples. We found no significant variation in utilization of prey based on climatic season or harvest schedule. Most other studies also did not note significant seasonal changes in diet (Alcala \& Brown 1969; Inoue 1972; Lekagul \& McNeely 1977; Santiapillai \& Suprahman 1985; Rabinowitz 1990; Sakaguchi \& Ono 1994; Tatara \& Doi 1994; Grassman 1998; Grassman 2000; Grassman et al. 2005; Austin et al. 2007; Rajaratnam et al. 2007; Fernandez \& de Guia 2011).

We note that a brief earlier study (Fernandez \& de Guia 2011) in the area also reported heavy reliance of leopard cats on exotic pest rodents: Mus musculus (96\%) and Rattus tanezumi (96\%) occurred most frequently in 25 samples (Fernandez \& de Guia 2011). This study also reported $R$. argentiventer hair from the scats they collected from the area; this species has not been confirmed for the island though it is possible that it occurs on Negros (Heaney et al. 2010). Identifications of mammals based on hairs in scats, which are prone to morphological variability between individuals of the same species, are thought to be difficult to determine with certainty (Mayer 1952; Dagnall 1995; Broeck et al. 2000).

Our results strongly support previous evidence that sugarcane plantations on Negros Island with only very small and scattered patches of non-agricultural vegetation support populations of leopard cats throughout the year, and that reproduction occurs within these populations. Clearly, leopard cats have been able to adapt to the massive conversion of their native forest habitat to sugarcane fields that began in the 1850s (Larkin 1993), the widespread logging on the island in the $1900 \mathrm{~s}$ onwards (Kummer 1992), and the current threats from illegal pet trade and poaching (Lorica \& Oliver 2006). In doing so, the cats have shown flexibility both in their use of habitat and in their use of prey: in this study, the great majority of their food consisted of exotic pest species of rats and mice. Thus, our findings are consistent with the prediction by Watanabe (2009) that leopard cats on islands that have few or no native mammalian prey should show flexibility in prey selection, but this flexibility on Negros is manifested as a shift to overwhelming reliance on exotic rodents, rather than the shift to a wide range of vertebrates and invertebrates predicted by Watanabe. Overall, the ability of this carnivorous mammal to survive in a highly anthropogenic habitat by utilizing non-native prey is remarkable, given the general vulnerability of mammalian carnivores to extinction.

\section{REFERENCES}

Alcala, A.C. \& W.C. Brown (1969). Notes on the food habits of three Philippine wild mammals. Silliman Journal 16: 91-94.

Austin, S.C., M.E. Tewes, L.I. Grassman Jr. \& N.J. Silvy (2007). Ecology and conservation of the Leopard Cat Prionailurus bengalensis and Clouded Leopard Neofelis nebulosa in Khao Yai National Park, Thailand. Acta Zoologica Sinica 53(1): 1-14.

Broeck, W.V., P. Mortier \& P. Simoens (2000). Scanning electron microscopic study of different hair types in various breeds of rabbits. Folia Morphologica 60(1): 33-40.

Brown, J.H. (1971). Mammals on mountaintops: Nonequilibrium insular biogeography. The American Naturalist 105(945): 467-478; http://dx.doi.org/10.1086/282738

Bumstead, P., D. Knapik \& W. Fitch (1992). Feline Facts. Society of Scientific Care, Inc., San Diego, CA, 88pp.

Dagnall, J.L. (1995). A simple negative staining technique for the identification of mammal hairs. Journal of Zoology 237(4): 670-675; http://dx.doi.org/10.1111/j.1469-7998.1995.tb05025.x

de Alwis, W.L.E. (1973). Status of South East Asia's small cats, pp. 198208. In: Eaton, R.L. (ed.). The World's Cats. World Wildlife Safari, Winston, Oregon.

Delibes, M., M.C. Blazquez, R. Rodriguez-Estrella \& S.C. Zapata (1997). Seasonal food habits of Bobcats (Lynx rufus) in subtropical Baja California Sur, Mexico. Canadian Journal of Zoology-Revue Canadienne De Zoologie 75(3): 478-483; http://dx.doi.org/10.1139/ z97-058

Fernandez, D. A. P. \& A. P. O. de Guia (2011). Feeding habits of Visayan Leopard Cats (Prionailurus bengalensis rabori) in sugarcane fields of Negros Occidental, Philippines. Asia Life Sciences 20(1): 143-154.

Grassman, L.I. (1998). Movements and prey selection of the Leopard Cat (Prionailurus bengalensis) in a sub-tropical evergreen forest in southern Thailand. Scientific Reports Società Zoologica La Torbiera 4: 7-21.

Grassman, L.I. (2000). Movements and diet of the Leopard Cat Prionailurus bengalensis in a seasonal evergreen forest in southcentral Thailand. Acta Theriologica 45(3): 421-426.

Grassman, L.I., M.E. Tewes, N.J. Silvy \& K. Kreetiyutanont (2005). Spatial organization and diet of the Leopard Cat (Prionailurus bengalensis) in north-central Thailand. Journal of Zoology 266: 4554; http://dx.doi.org/10.1017/S095283690500659X

Hall, R. (1996). Reconstructing Cenozoic SE Asia, pp. 153-184. In: Hall, R. \& D. Blundell (eds.). Tectonic Evolution of Southeast Asia. Geological Society of London Special Publication No. 106.

Hall, R. (2002). Cenozoic geological and plate tectonic evolution of SE Asia and the SW Pacific: Computer-based reconstructions, model and animations. Journal of Asian Earth Sciences 20(4): 353-431; http://dx.doi.org/10.1016/S1367-9120(01)00069-4

Heaney, L.R. (1984). Mammalian species richness on islands on the Sunda Shelf, south east Asia. Oecologia 61: 11-17; http://dx.doi. org/10.1007/BF00379083

Heaney, L.R., M.L. Dolar, D.S. Balete, J.A. Esselstyn, E.A. Rickart 
\& J.L. Sedlock (2010). Synopsis of Philippine Mammals. <http:// archive.fieldmuseum.org/philippine mammals/introduction.asp >. Accessed 29 December 2011.

Heideman, P.D., L.R. Heaney, R.L. Thomas \& K.R. Erickson (1987). Patterns of faunal diversity and species abundance of non-volant small mammals on Negros Island, Philippines. Journal of Mammalogy 68(4): 884-888; http://dx.doi.org/10.2307/1381575

Hemmer, H. (1976). Gestation period and postnatal development in felids, pp. 143-165. In: Eaton, R.L. (ed.). The World's Cats - Volume 3. Carnivore Research Institute, University of Washington, Seattle.

Inoue, T. (1972). The food habits of the Tsushima Leopard Cat, Felis bengalensis ssp., analyzed from their scats. Journal of the Mammalogical Society of Japan 5: 155-169.

Institute of Environmental Science for Social Change (ESSC) (2002). Philippine forest cover (2002) map series.

Joshi, A.R., J.L.D. Smith \& F.J. Cuthbert (1995). Influence of food distribution and predation pressure on spacing behavior in Palm Civets. Journal of Mammalogy 76(4): 1205-1212; http://dx.doi. org/10.2307/1382613

Khan, M.N.H. (2004). Food habit of the Leopard Cat Prionailurus bengalensis (Kerr, 1792) in the Sundarbans East Wildlife Sanctuary, Bangladesh. Zoos' Print Journal 19(5): 1475-1476; http://dx.doi. org/10.11609/JoTT.ZPJ.1101.1475-6

Kummer, D.M. (1992). Deforestation in the Postwar Philippines. The University of Chicago Press, Chicago, xvii+201pp.

Larkin, J.A. (1993). Sugar and the Origins of Modern Philippine Society. Berkeley: University of California Press, Berkeley, xvi+337pp.

Lawlor, T.E., D.J. Hafner, P. Stapp, B.R. Riddle \& S.T. Alvarez-Castañeda (2002). Mammals, pp. 326-361. In: Case,T.J., M.L. Cody \& E. Ezcurra (eds.). A New Island Biogeography of the Sea of Cortés. Oxford University Press, New York.

Lekagul, B. \& J.A. McNeely (1977). Mammals of Thailand. Association for the Conservation of Wildlife, Bangkok, 758pp.

Lomolino, M.V., B.R. Riddle, R.J. Whittaker \& J.H. Brown (2010). Biogeography. Sinauer Associates, Inc., Sunderland, Massachusetts, $\mathrm{xi}+878 \mathrm{pp}$.

Lorica, M.R.P. \& W.L.R. Oliver (2006). Distribution and habitat utilization of the Visayan Leopard Cat Prionailurus bengalensis rabori. Banwa 3(1\&2): 132-144.

Lorica, R. (2008). Prionailurus bengalensis ssp. rabori. In: IUCN 2009 IUCN Red List of Threatened Species. Version 2009.2.2008 . < http:// www.iucnredlist.org/details/136889/0>. Accessed 28 October 2011.

Mayer, W.V. (1952). The hair of California mammals with keys to the dorsal guard hairs of California mammals. The American Midland Naturalist 48(2): 480-512.

McDonald, J.H. (2009). Fisher's Exact Test of Independence, pp. 7075. In: McDonald, J.H. (ed.). Handbook of Biological Statistics - $2^{\text {nd }}$ Edition. Sparky House Publishing, Baltimore, Maryland.

Nakashima, Y., E. Inoue \& M. Inoue-Murayama (2010). Functional uniqueness of a small carnivore as seed dispersal agents: a case study of the Common Palm Civets in the Tabin Wildlife Reserve, Sabah, Malaysia. Oecologia 164: 721-730; http://dx.doi.org/10.1007/ s00442-010-1714-1

Nawa, A. (1968). Observations on the breeding habits and growth of Prionailurus bengalensis manchurica in captivity. Journal of the Mammalogical Society of Japan (in Japanese, English summary) 4: 12-19.

Nowak, R.M. (2005). Walker's Carnivores of the World. The Johns Hopkins University Press, Baltimore, 331pp.

Nowell, K. \& P. Jackson (1996). Wild Cats: Status Survey and Conservation Action Plan. World Conservation Union, Gland, Switzerland, xxiii+406pp.

Pedregosa, M., L.M. Paguntalan, P.G. Jakosalem, E. Lilio, E.L. Rico, D.J. de Alban, R. Lorica, E. Lastica \& F. Enricoso (2006). An Assessment of the Native Flora and Fauna of Sicogon Island, Panay, Philippines. Fauna and Flora International-Philippines, Philippines, 44pp.

Primack, R.B. (1993). Essentials of Conservation Biology. Sinauer Assoc., Inc., Sunderland, Massachusetts, 467-478pp.
Rabinowitz, A.R. (1990). Notes on the behavior and movements of Leopard Cats, Felis bengalensis, in a dry tropical forest mosaic in Thailand. Biotropica 22(4): 397-403; http://dx.doi. org/10.2307/2388557

Rabinowitz, A.R. (1991). Behavior and movements of sympatric civet species in Huai Kha Khaeng Wildlife Sanctuary, Thailand. Journal of the Zoological Society of London 223: 281-298; http://dx.doi. org/10.1111/j.1469-7998.1991.tb04765.x

Rabor, D.S. (1977). Philippine Birds \& Mammals. Published for the U.P. Science Education Center by the University of the Philippines Press, Quezon City, 284pp.

Rajaratnam, R., M. Sunquist, L. Rajaratnam \& L. Ambu (2007). Diet and habitat selection of the Leopard Cat (Prionailurus bengalensis borneoensis) in an agricultural landscape in Sabah, Malaysian Borneo. Journal of Tropical Ecology 23(2): 209-217; http://dx.doi. org/10.1017/S0266467406003841

Sakaguchi, N. (1990). Habitat use of the Iriomote cat and changes in its response to prey availability, pp. 137-140. In: Maruyama, N., B. Bobek, Y. Ono, W. Regelin, L. Bartos \& P.R. Ratcliffe (eds.). Wildlife Conservation: Present Trends and Perspectives for the 21st Century. Japan Wildlife Research Centre, Tokyo.

Sakaguchi, N. \& Y. Ono (1994). Seasonal change in the food habits of the Iriomote cat Felis iriomotensis. Ecological Research 9: 167-174; http://dx.doi.org/10.1007/BF02347492

Santiapillai, C. \& H. Suprahman (1985). On the Status of the Leopard Cat (Felis bengalensis) in Sumatra. World Wildlife Fund/International Union for the Conservation of Nature and Natural Resources, 8-13pp.

Scott, D.M. \& E. Gemita (2004). Can Human-Modified Landscapes in Sumatra Provide Suitable Habitat for Threatened Cat Species? University of Brighton, Brighton, UK, 33pp.

Shore, R., W. Meek, T. Sparks, R. Pywell \& M. Nowakowski (2005). Will environmental stewardship enhance small mammal abundance on intensively managed farmland? Mammal Review 35(3-4): 277284; http://dx.doi.org/10.1111/j.1365-2907.2005.00072.x

Stenseth, N.C., H. Leirs, A. Skonhoft, S.A. Davis, R.P. Pech, H.P. Andreassen, G.R. Singleton, M. Lima, R.S. Machang'u, Z. Zhang, P.R. Brown, D. Shi \& X. Wan (2003). Mice, rats, and people: The bio-economics of agricultural rodent pests. Frontiers in Ecology and the Environment 1(7): 367-375; http://dx.doi.org/10.1890/15409295(2003)001[0367:MRAPTB]2.0.CO;2

Steppan, S.J., C. Zawadzki \& L.R. Heaney (2003). Molecular phylogeny of the endemic Philippine rodent Apomys (Muridae) and the dynamics of diversification in an oceanic archipelago. Biological Journal of the Linnean Society 80: 699-715; http://dx.doi.org/10.1111/j.10958312.2003.00274.x

Sunquist, M.E. \& F. Sunquist (2002). Wild Cats of the World. University of Chicago Press, 452.

Tatara, M. \& T. Doi (1994). Comparative analyses on food habits of Japanese Marten, Siberian Weasel and Leopard Cat in the Tsushima Islands, Japan. Ecological Research 9(1): 99-107; http://dx.doi. org/10.1007/BF02347247

Taylor, E.H. (1934). Philippine Land Mammals. Monographs of the Bureau of Science No. 30, 48pp+25pls.

Watanabe, S. (2009). Factors affecting the distribution of the Leopard Cat Prionailurus bengalensis on East Asian Islands. Mammal Study 34: 201-207; http://dx.doi.org/10.3106/041.034.0404

Watanabe, S. (2004). Flexibility of food habit, habitat use, and movement pattern of the Iriomote Cat (Prionailurus bengalensis iriomotensis) as the adaptation to the insular environment. PhD Thesis. University of the Ryukyus, Okinawa, Japan, 136pp.

Whittaker, R.J. \& J.M. Fernández-Palacios (2007). Island Biogeography: Ecology, Evolution and Conservation. Oxford University Press, Oxford, xii+401.

Yasuma, S. (1981). Feeding behaviour of the Iriomote Cat (Prionailurus iriomotensis Imaizumi, 1967). Bulletin of the Tokyo University Forests 70: 81-140. 